\title{
Identity and Representation: Does 'Name' Matter As An Element of Statehood?
}

\author{
Kawser Ahmed* \\ DOI: 10.21827/GroJIL.9.1.22-42
}

\section{Keywords:}

CRITERIA OF STATEHOOD ; NAME OF STATE; IDENTITY; GREECE; MACEDONIA

\begin{abstract}
No state is born sans a name. The widely accepted view is that a state comprises its population, the geographical territory, the ruling government and capacity to enter into relations with other states. This paper argues that in addition to these traditionally recognised requirements, the name of a state, as the most suitable signifier of its identity, deserves to be recognised as an element of statehood. The reason for establishing a state is to create conditions as well as justification for exercising sovereign power, which ipso facto requires manifestation of its identity. This expected function seems impracticable at least in an international setting if a state does not have any name at all. The name of a state serves as the most efficacious vehicle for manifesting its identity as a legal entity. Moreover, practices concerning the name and naming of the prospective states show that it has been regarded as a crucial desideratum by the actors concerned in the course of attainment of statehood.
\end{abstract}

\section{Introduction}

Can we imagine a state without a name? There is not, and cannot be, an anonymous state. Undeniably, the name of a state, as long as the state exists, remains an inseparable part of its identity. On the other hand, the name and naming of a state or a prospective state seldom appears as a substantive legal issue in international law. In the past, there have emerged only a handful of cases of States having dissented over the issue of name, such as the change of name from German Austria (Deutschösterreich) to Austria ${ }^{1}$ and the discontent between Ireland and the United Kingdom of Great Britain between 1937 and 1998 about their respective official designations. ${ }^{2}$ The more recent instances of disputes over state titles include the non-usage of the name Myanmar ${ }^{3}$ by the United States and some other countries; Greece's objection to the erstwhile title of North Macedonia ${ }^{4}$, and the People's Republic of China's (China) opposition to Republic of

* LL.M. (MIDS), LL.M. (NYU). Advocate, Supreme Court of Bangladesh. Consultant, The Ministry of Foreign Affairs of Bangladesh. Adjunct Faculty, Faculty of Law, Jahangirnagar University, Dhaka. The author would like to thank Dr. Lyal S. Sunga, Professor Dr. Md. Rizwanul Islam and Muhammad Rezaur Rahman for their comments on an earlier draft. The views expressed here are those of the author alone.

1 Michael Ioannidis, 'Naming a State-Disputing over Symbols of Statehood at the Example of Macedonia' (2010) 14 MaxPlanckUNYB 538-545.

2 ibid 532-538.

3 Lowell Dittmer, 'Burma vs. Myanmar: What's in a Name?' in Lowell Dittmer (ed.), Burma or Myanmar? The Struggle for National Identity (World Scientific Publishing Co. Pte. Ltd. 2010) 2-120.

4 See Irena Stawowy-kawka and Tadeusz Stanek, 'The Greco-Macedonian Dispute Over the Name of The Republic of Macedonia' (2008) 10(1) Politeja 223-40. 
China as the official designation of Taiwan ${ }^{5}$. Especially, the dispute between Greece and Macedonia over the latter's name in the first quarter of the 1990s constitutes a unique case in point. In the Greco-Macedonian name dispute, the refusal of the EC and Greece to grant recognition until replacement of the name Republic of Macedonia with some other 'acceptable' name verily points to the question: does the name really matter in connection with the emergence of new states? A moment's reflection makes it crystal clear that a state's name serves as the vehicle for manifesting its unique identity, and thus, helps it to function both internally and externally as a juristic person. If population, territory, government ${ }^{6}$ and capacity to enter into relations with other states do qualify as elements of statehood ${ }^{7}$ because they are the desiderata in absentia of which attainment of statehood remains incomplete and the state is rendered incapacitated to function, it also stands to reason that a state's name should be accorded similar status.

This article argues that in addition to population, territory, government and capacity to enter into relations with other states, the name of a state as the most suitable signifier of its identity deserves to be counted as an element of statehood, even if it has not been so recognised in any multilateral conventions or customary international law. A satisfactory vindication of the aforesaid proposition will require to establish that, from emergence to extinction, a state's identity or name remains an ineluctable feature of its legal personality. To that end, the following questions will be addressed: whether attainment of statehood could be said to have been complete in absence of any representative identity or name of the entity aspiring to become a state, and whether a state can do without any representation of its identity throughout its existence. At the very outset, we will see that in today's world of extremely complex international legal relationships, a state can barely thrive without manifesting its identity, and for the same reason it is impossible to obviate the importance of state name. We then examine practices concerning the name and naming of the prospective states, in order to illustrate the fact that the manifestation of the identity of a state through the adoption of a representative name has always been regarded as a crucial desideratum in the course of the creation of new states. Discussion on unilateral change of the state name as well as the extinction thereof will uphold the argument that a state during its lifetime simply cannot afford to dispense with the manifestation of its identity. Lastly, the article focuses on legal issues concerning the name and naming of states with particular reference to the Greco-Macedonian name dispute. The article concludes with the observation that in a world of multifarious relationships among states, the functionality of a state's identity or name is as important as the other elements of statehood recognized hitherto. In this article, the terms, 'identity' and 'name' will be used interchangeably.

5 Taiwan is also known as Chinese Taipei. See J Y, 'What is "Chinese Taipei"?' (The Economist, 9 April 2018) <https://www.economist.com/the-economist-explains/2018/04/09/what-is-chinese-taipei> accessed 16 August 2021.

6 Although attainment of statehood requires the presence of an effective and independent government, a lack of government does not render legal existence of a state defunct. See Brad R Roth, Governmental Illegitimacy in International Law (OUP 1999) 130-131.

7 Convention on Rights and Duties of States (signed 26 December 1933, entered into force 26 December 1934) (hereinafter Montevideo Convention) art 1; For the purpose of this article, the author has used the terms State and Statehood alternatively. On statehood see generally James Crawford, 'The Criteria of Statehood in International Law' (1976) 48 British Yearbook of International law 93; Johan David Van der Vyver, 'Statehood in International Law' (1991) 5 Emory International Law Review 15; D J Devine, 'The Requirements of Statehood Re-examined' (1971) 34(4) Modern Law Review 410; Rosalyn Cohen, 'The Concept of Statehood in United Nations Practice' (1961) 109 University of Pennsylvania Law Review 1127; Ian Brownlie, The Rule of Law in International Affairs (Martinus Nijhoff Publishers 1998) 35-39. 


\section{Importance of State Name: Identity and Representation}

The concept of statehood occupies a pivotal place in the study of international law. Although the elements of statehood as provided in the Montevideo Convention are generally acknowledged by the jurists, the contemporary textbooks on public international law seldom discuss why population, territory, government and capacity to enter into relations with other states should qualify as elements of statehood. Also noteworthy is the divergence of opinion among the scholars in this regard. According to one school of thought, the elements of statehood are strictly laid down by the law. ${ }^{8}$ Conversely, in the opinion of Professor Ian Brownlie, the traditional elements of statehood should be regarded as nothing more than a mere basis for further investigation, and in any case, further elements must be employed to produce a working legal definition of statehood..$^{9}$ Other scholars opine that the Montevideo list is incomplete, ${ }^{10}$ or that the relationship between factual and legal elements of statehood is a shifting one ${ }^{11}$ or that there is no generally accepted definition of statehood at all ${ }^{12}$. There is no gainsaying that this article takes cue from Professor Ian Brownlie's view in advocating its argument that a state's name, being the most suitable manifestation of its identity, deserves to be ranked as an element of statehood. The reason is not only that the actors concerned regarded identity or name of a state or prospective state as an important matter in the course of inception of new states, but also that a state's identity has certain other important bearings too, like other traditional elements of statehood. An obvious reason for having a state is to create conditions as well as justification for exercising sovereign power as a distinct member of the international community ${ }^{13}$. This very function is hard to come by without representation and exertion of the legal personality ${ }^{14}$ of a state. And, needless to reiterate, representation of a state's legal personality requires an identity which is most conveniently and effectively manifested through its name.

As already indicated, a state's identity entails both practical and symbolic implications. Geographical location, language, historical past, ${ }^{15}$ political ideology \& system, religious faiths, cultural disposition of the inhabitants - all of these indefatigably and wholesomely contribute to the creation of the identity of a state. It is noticeable that these elements are more or less reflected in the name of a state. For instance, the presence of expressions such as Republic, People's Republic, Islamic Republic, Federal Republic, Democratic Republic, United Republic, United States, Emirate, Union, Duchy, Kingdom, United Kingdom, Empire, State, City State, Federated States, Independent State, Federation, Confederation, Dominion, Commonwealth, Principality etc. in the formal title of a state does convey quite a bit of information about that state. On a practical level, the traditionally recognised elements of statehood, namely, population, territory, government and capability to enter into relations with other states as well as their mutual complex relationship are identified with a state's name. Such as, a government exercises sovereign power in the name of state. In other words, the functions

\footnotetext{
James Crawford, Brownlie's Principles of Public International Law (9 ${ }^{\text {th }}$ edn, OUP 2019) 117.

Ian Brownlie, Principles of Public International Law (4th edn, OUP 1990, Reprint 1993) 72.

Jan Klabbers, International Law (2nd edn, CUP 2017) 75.

11 Malcom N Shaw, International Law ( $8^{\text {th }}$ edn, CUP 2017) 157.

12 Karen Knop, 'Statehood: territory, people, government' in James Crawford and Martti Koskenniemi (eds), The Cambridge Companion to International Law (CUP 2012) 95.

13 Antonio Cassese, International Law ( $2^{\text {nd }}$ edn, OUP 2005) 22-44.

14 Brownlie (n 9) 36; Professor Ian Brownlie has proposed a number of indicators for legal personality of state.

15 Robert Redslob, 'The Problem of Nationalities' (1932) 17 Transactions of the Grotius Society 22-23; Redslob said that the remembrance of past time was a chief element for constituting a nation.
} 
of a state are carried out in its name since a state can act only by and through its agents. ${ }^{16}$ Furthermore, an individual sovereign while describing His or Her sovereign title usually makes reference to the official name of the state over which $\mathrm{He}$ or She claims to hold sway. ${ }^{17}$ The importance of a state's identity or name makes even more sense for a government in exile, who claims to be the sole legitimate government of that state. In absence of any actual control over population and territory, the only way a government in exile can relate to the state it claims to represent is by identifying itself with the designation of such state. ${ }^{18}$ In addition, the practice of adopting the geographical name of a territory as the name of state points to the identity issue. The concept of fixed-frontier state $^{19}$ could well be a reason for such practice. Again, creation of a state requires that there must be a reasonably stable political community in control of a given territory. ${ }^{20}$ Nationality of the members of such political community is determined with reference to the identity and name of the state concerned. In fine, it can be restated that a state's name embodies all other elements of statehood and their mutual relationship in a single denomination and thus serves as the representative identity of a state.

The contemporary international legal orders are premised on the concept of the sovereignty of states. Meaningful engagement with the international community requires manifestation and representation of the identity of a state - which is most effectively served by its name. Attribution of state responsibility, exercise of jurisdiction, determination of nationality, diplomatic protection, signing treaties, succession to treaties, membership and representation in the international organizations, settlement of disputes by judicial means - all buttress the fact that every single state is absolutely required to possess representative identity for participation in the system of the presentday international community. In addition, the identity or name of a state or prospective state entails essential significance in the practice of recognition of the government and the state. It is quite unthinkable that a state, without even a name, would be able to discharge the aforesaid functions in an international setting.

Even, the putative identity or name of a prospective state bears considerable importance. The declaration of the prospective name of a state allows its founders to demonstrate publicly their political will to establish a state. Adoption of a name for a forthcoming state by an aspiring population may signify the initiation of a political process to that end. For instance, the name Pakistan was proposed for the envisaged sovereign state of the Muslim populace of the then Federation of India ${ }^{21}$ long before its statehood had materialised..$^{22}$ At that time, the very proposition of the name Pakistan set the agenda for creating a separate political identity of the Muslim populations in India. In other cases, adoption of official name for the entity which is due to emerge as a state

16 Settlers of German Origin in Poland (Advisory Opinion) 1923 PCIJ Series B No 6 [22].

17 For example, the royal style and title of King George V was as follows: 'George V. by the Grace of God of Great Britain, Ireland and of the British Dominions beyond the Seas King; Defender of the Faith, Emperor of India'. The London Gazette (13 May 1927).

18 There can be no government without the state which it claims to belong to, let alone a government in exile. See Lighthouses in Crete and Samos (Judgment) 8 October 1937 PCIJ Series A/B No. 71 [103].

19 The Peace of Westphalia of 1648 marked a crucial point towards creation of modern states based upon defined territorial units. See Arthur Nussbaum, A Concise History of the Law of Nations (The Macmillan Company 1954) 115-118.

20 Brownlie (n 9) 72-73.

21 The Government of India Act (1935) 26 Geo 5 Ch 2, s 5.

22 The Indian Independence Act (1947) 10 \& 11 Geo 6 Ch 30, s 1 . The name, Pakistan was proposed by Choudhary Rahmat Ali in 1933. See Choudhary Rahmat Ali, 'Now or Never: Are we to live or perish porever?' (1933) (The Pakistan Declaration) <http://www.columbia.edu/itc/mealac/pritchett/00islamlinks/txt_rahmatali_1933.html> accessed 5 August 2020. 
may suggest that all the traditional elements of statehood have already been met. Such as, when the United Nations successfully concluded the transitional administration of East Timor, it was with the adoption of designation of the Democratic Republic of Timor-Leste, that the attainment of statehood became formally complete. ${ }^{23}$

In the end, it can be said that the name of a state or prospective state entails immense legal and political implications. While a state's name serves as the signifier of its identity as a sovereign entity, for a prospective state it serves, among others, as a metaphor for its actual or envisaged existence. History evinces that states rarely change their names although in theory they have the sovereign right to adopt any names anytime they think appropriate. Plausibly, the reason is that it takes the struggle of many generations to build a nation, construct a national identity and attain statehood. Thus, it explains why the identity or name matters both practically and symbolically in the course of creation of new states.

\section{Practice concerning Name and Naming of the Prospective States}

There is a wide range of practices concerning name and naming of the prospective states by different actors in different capacities. In this part, we shall examine them in order to show that public manifestation of a forthcoming state's identity through the adoption of a name is in fact regarded as crucial desiderata in the course of creation of new states. For example, a state or a sovereign may designate a certain name to any of its constituent units at the time of granting independence. Two or more states may adopt a new name while being unified into a single state. A constituent unit of a state, upon attaining independence, may adopt such a name as would indicate its newly acquired sovereign status. These are but some of the examples that depict practices concerning the naming of the prospective states in the exercise of sovereign capacity.

However, the above paradigms will not be able to shed light on the practices concerning adoption of a representative name for any prospective states by the nonsovereign actors pending attainment of statehood. For instance, the founders of a forthcoming state may pronounce its name quite ahead of the formal attainment of statehood. An aspiring political entity may develop into a state all by itself or may attain statehood by breaking away from an extant state or sovereign. A declaration of the would-be name of a state pending formal attainment of statehood in the aforesaid situations is a common practice. As opposed to the sovereign capacity, we shall characterise these examples as naming of the prospective states in the exercise of the constituent capacity. ${ }^{24}$ The constituent capacity of a population aspiring to statehood can be represented by a political party or organisation, liberation force, provincial ruler or government, government in exile, any person, prince, leader or a collegial body etc.

23 See UNSC Presidential Statement (2002) UN Doc S/PRST/2002/13. On the same day, the Prime Minister of the Democratic Republic of East Timor submitted the application for admission to the UN. See UNSC 'Application of the Democratic Republic of East Timor for Admission to Membership in the United Nations' (2002) UN Doc A/56/953-S/2002/558 Annex; In the French version of the application the name of the applicant state was written as la République démocratique du Timor oriental.

24 In this article, the political potential of a population to establish and maintain statehood is understood as the constituent capacity. It should be noted that the author has used the term 'constituent capacity' instead of 'constituent power'. For detail discussion about constituent power see Martin Loughlin, The Idea of Public Law (OUP 2009) 99-113. 
The justification for any act done in exercise of the constituent capacity may be claimed to have been derived from a number of sources like de facto control, representation of the popular will, referendum, self-determination, recognition by the possessors of the sovereign capacity ${ }^{25}$ and recognition by the international organizations ${ }^{26}$ etc. The fact of the matter remains that the ultimate legitimacy of such acts done in the exercise of the constituent capacity would depend on the successful transformation of the possessors of the constituent capacity into the possessors of the sovereign capacity in a formal sense. An account of practices concerning name and naming of forthcoming states in the exercise of both the sovereign capacity and the constituent capacity will help illustrate the proposition of this article that adoption of name for a prospective state has been regarded as an important issue in the course of emergence of new states.

\section{A. Designating a Forthcoming State's Name in Exercise of Sovereign Capacity}

There are countless examples to testify that a state or a sovereign may grant independence to any of its territories, constituent units or dependencies under its control. Accordingly, identifying a constituent unit by name as an independent state by the extant state, or unification of two or more states into a single state and the consequent adoption of a new name entails exercise of sovereign capacity. The act of naming a forthcoming state in the exercise of sovereign capacity may come about in a number of ways that include legislation, international treaty, sovereign acts etc.

A state or a sovereign may identify by name any of its territories, parts, dependencies or constituent units as independent through legislative act or action. For example, the Indian Independence Act, 1947 provided, "As from the fifteenth day of August, nineteen hundred and forty seven, two independent dominions shall be set up in India to be known respectively as India and Pakistan". ${ }^{27}$ The said Act further provided that His Majesty's Government in the United Kingdom would have no responsibility with respect to the government of any of the territories which, immediately before that day, were included in British India; the suzerainty of His Majesty over the Indian states would lapse. ${ }^{28}$ Southern Rhodesia was declared independent under the name of Zimbabwe by virtue of the authority of the Zimbabwe Act $1979 .{ }^{29}$ The Union of South Africa was the designation of the legislative union comprising the colonies of the Cape of Good Hope, Natal, the Transvaal and the Orange River Colony. ${ }^{30}$ The Statute of Westminster, 1931 extended the status of Dominion to the Union of South Africa ${ }^{31}$ and this particular designation continued to be in use till 1961 in which year, the Union of South Africa became a republic and accordingly changed its name to the Republic of South Africa. ${ }^{32}$ The formal name and style, the Republic of South Africa recurred in subsequent constitutions. ${ }^{33}$

25 According to the author, legal recognition of the possessors of the constituent capacity by any state or sovereign does not necessarily confer equal status on the former.

26 For example, the Palestine Liberation Organization (PLO) was invited to participate in the UN as an observer. See UNGA Res 3237 (XXIX) (22 November 1974) UN Doc A/RES/3237 (XXIX) [3].

27 The Indian Independence Act (n 22) s 1.

28 ibid s 7.

29 The Zimbabwe Act (1979) Elizabeth II Ch 60, s 1.

30 The South Africa Act (1909) 9 Edw 7 Ch 9, ss 4, 6 \& 7.

31 The Statute of Westminster (1931) 22 Geo 5 Ch 4, s 4.

32 See CEC and CMC, 'South Africa's Withdrawal and What It May Mean' (1961) 17(4) The World Today 135.

33 See South African Constitution (1996) art 1. See also South Africa (Interim) Constitution (1993) art 1. 
As mentioned above, a state or a sovereign may also identify by international treaty any of its dependencies or constituent units as an independent state. By the Paris Peace Treaty of 3rd September, 1783, the then King of Great Britain had recognized New Hampshire, Massachusetts Bay, Rhode Island and Providence Plantations, Connecticut, New York, New Jersey, Pennsylvania, Delaware, Maryland, Virginia, North Carolina, South Carolina and Georgia, collectively known as the United States, to be free sovereign and independent states. ${ }^{34} \mathrm{~A}$ more complex example would be the Anglo-Irish Treaty. ${ }^{35}$ Poblacht na hÉireann ${ }^{36}$ or the Irish Republic was proclaimed in the island territory known as Ireland in 1916 by the nationalist rebels who launched the Easter Rising and were also eventually subdued. ${ }^{37}$ The Irish Republic was construed to comprise the whole island of Ireland. On the other hand, the British Government passed the Government of Ireland Act, 1920 and partitioned Ireland into two territorial units named, Northern Ireland and Southern Ireland. Both the areas were declared to continue as parts of the United Kingdom. ${ }^{38}$ In the Anglo-Irish Treaty, Ireland was granted the status of a dominion under the designation of Irish Free State ${ }^{39}$ comprising both Northern Ireland and Southern Ireland. It also provided that Northern Ireland could opt out of the Irish Free State. ${ }^{40}$ The Parliament of Northern Ireland resolved on 7th December 1922, that the powers of the Parliament and Government of the Irish Free State would not extend to Northern Ireland. The designation, Irish Free State, however, continued until 1937. The 1937 Constitution changed the name of the state to Éire or Ireland. ${ }^{41}$

The creation of independent states or recognition of sovereign status by multilateral treaty, especially in the course of peace settlement in the aftermath of great wars had been a time-honoured practice even until the middle of the twentieth century. ${ }^{42}$ In such treaties, states which were sought to be created or recognised were identified by their respective names. For example, article I of the London Protocol of 3 February 1830 provided: "Greece shall form an independent State, and shall enjoy all the rights, political, administrative, and commercial, attached to complete independence." ${ }^{\prime 3}$ In the

34 The Definitive Treaty of Peace Between the Kingdom of Great Britain and the United States of America (signed 3 September 1783) (Treaty of Paris) art 1 <http://avalon.law.yale.edu/18th_century/paris.asp.> accessed 02 March 2013.

35 Officially known as the Articles of Agreement for a Treaty between Great Britain and Ireland <http://www.nationalarchives.ie/topics/anglo_irish/dfaexhib2.html> accessed 27 March 2013; The Anglo-Irish Treaty was signed in London on 6 December 1921.

36 In 1916 the republic was described in Irish as Poblacht and on its re-proclamation in 1919 it was called Saorstát. See Michael Laffan, The Resurrection of Ireland (CUP 2004) 350.

37 See David G Boyce, "'British Opinion, Ireland, and the War', 1916-1918” (1974) 17(3) The Historical Journal 578. See also John Newsinger, 'James Connolly and the Easter Rising' (1983) 47(2) Science \& Society 173-177. See Paul Bew, 'Moderate Nationalism and the Irish Revolutions' (1999) 42(3) The Historical Journal 735; In the 1918 general election, Sinn Féin came out as overwhelmingly victorious. William H Kautt, The Anglo-Irish War, 1916-1921: A People's War (Praeger, 1999) 70-71.

38 Kautt (n 37). See also the Government of Ireland Act (1920) 10 \& 11 Geo 5 Ch 67, s 1 <http://www.legislation.gov.uk/ukpga/1920/67/pdfs/ukpga_19200067_en.pdf> accessed 14 July 2013.

39 The Anglo-Irish Treaty ( $\mathrm{n}$ 35); The term Irish Free State appeared in article 1 of the Treaty.

40 ibid art 12.

41 The 1937 Constitution changed the name of the state to Éire or Ireland. Article 5 of the Constitution provides, "Ireland is a sovereign, independent democratic state." See Mary E Daly, 'The Irish Free State/ Éire/Republic of Ireland/Ireland: "A Country by Any Other Name”?' (2007) 46 Journal of British Studies 76.

42 See generally James Crawford, The Creation of States in International Law (OUP 2007) 504-522.

43 'Protocol of Conference between Great Britain, France, and Russia, Relative to the Independence of Greece' art 1 (signed 3 February 1830) reprinted in Sir Augustus Oakes and R B Mowat (eds), The Great European Treaties of the Nineteenth Century (OUP 1918) 120. 
Congress of Berlin of 1878, the Great Powers referred to Montenegro, Serbia and Romania by name while dealing with the issue of their independence. ${ }^{44}$

Adoption of a new identity at the time of creation of a new state by the unification of two or more states signifies the exercise of sovereign capacity. The designation "United Republic of Tanganyika and Zanzibar" was attributed to the new state that emerged as a result of integration of the Republic of Tanganyika and the People's Republic of Zanzibar under the Articles of Union of 22 April 1964. ${ }^{45}$ Initially, the Articles of Union referred to the forthcoming state as the United Republic. ${ }^{46}$ In order to give effect to the Articles of Union, both the government of Tanganyika and the government of Zanzibar passed laws ${ }^{47}$ providing that the Republic of Tanganyika and the People's Republic of Zanzibar would merge into one sovereign republic by the name of the United Republic of Tanganyika and Zanzibar. ${ }^{48}$ The adoption of the name the United Arab Republic (U.A.R.) ${ }^{49}$ for the single state created as a result of the unification of the Syrian Arab Republic ${ }^{50}$ and Egypt in $1958^{51}$ constitutes another example. ${ }^{52}$ Other examples include the name the Republic of Yemen for the single state that the People's Democratic Republic of Yemen ${ }^{53}$ and Yemen Arab republic ${ }^{54}$ have brought forth by their merging with each other. ${ }^{55}$

44 Article XXVI, XXXIV and XLIII of the Treaty of 13 July 1878 respectively recognised independence of Montenegro, Serbia and Romania. The spelling of Serbia and Romania appeared as Servia and Roumania respectively. See 'Treaty between Great Britain, Germany, Austria, France, Italy, Russia, and Turkey for the Settlement of Affairs in the East' (signed 13 July 1878) reprinted in (1908) 2(4) AJIL 401-424.

45 See Articles of Union between the Republic of Tanganyika and the People's Republic of Zanzibar (signed 22 April 1964) art (i) reprinted in 3 ILM (1964) 768.

46 ibid art (ii).

47 The People's Republic of Zanzibar on 25 April 1964 passed the Union of Zanzibar and Tanganyika Law, 1964; Ibid 763-768; On the same day, the Republic of Tanganyika passed the Union of Tanganyika and Zanzibar Act (1964) <http://www.wipo.int/wipolex/en/text.jsp?file_id=245022> accessed 14 August 2013.

48 See the Union of Zanzibar and Tanganyika Law (1964) ss 2 \& 4; the Union of Tanganyika and Zanzibar Act, 1964, ss 2 \& 4. See also Interim Constitution Decree (26 April 1964) reprinted in 3 ILM (1964) 772.

49 See Proclamation of the United Arab Republic (signed 1 February 1958), reprinted in (1959) 8 ICLQ 372-373.

50 The Syrian Arab Republic was an original member of the United Nations; see UN Documentation Search Guide, 'Founding Members' <https://research.un.org/en/unmembers/founders> accessed 16 August 2021.

51 The process of unification started with a number of resolutions passed by the Syrian political parties as well as the Syrian parliament calling for Arab unity and union of Egypt and Syria. See Monte Palmar, 'The United Arab Republic: An Assessment of its Failure' (1966) 20 Middle East Journal 50-51.

52 The Government of the United Arab Republic declared that the Union henceforth would be a single member of the United Nations. See UNSC 'Note Verbale dated 7 March 1958 from the SecretaryGeneral to the President of the Security Council' (7 March 1958) UN Doc S/3976 Annex A.

53 The People's Democratic Republic of Yemen was admitted to the UN under the name of the People's Republic of Southern Yemen. See UNGA Res 2310 (XXII) (14 December 1967) UN Doc A/RES/2310 (XXII).

54 Yemen Arab Republic was admitted to the UN under the name of Yemen. UNGA Res 109 (II) (30 September 1947) UN Doc A/RES/108 (II). See also UNSC Res 29(1947) (12 August 1947) UN Doc S/RES/29(1947).

55 By a letter dated 19 May 1990 the People's Democratic Republic of Yemen and the Yemen Arab Republic jointly informed the UN Secretary-General that they would merge in a single sovereign state to be called the Republic of Yemen as of 22 May 1990 with the resultant effect that the Republic of Yemen would have single membership in the UN. See UNGA 'Note Verbale dated May 21, 1990 from the Secretary General to the Permanent Representative of Member States' (22 May 1990) UN Doc A/44/946; For a background picture of the unification, see Robert D Burrowes, 'Prelude to 


\section{B. Designating a Forthcoming State's Name in Exercise of Constituent Capacity}

In addition to the foregoing, the emergence of new states may also come about in a number of ways, such as, unilateral establishment of state, secession, ${ }^{56}$ voluntary separation, etc. There are examples that in the aforementioned situations the founders generally declare independence in the name of a forthcoming state even before it has formally come into existence. Pending a prospective state's coming into formal legal existence, such act of naming signifies nothing but the constituent capacity of the founders of such forthcoming states. Evidently, the possessors of the constituent capacity, while seeking to establish a state often adopt such a name or manifest the prospective state's identity in such a manner as would signify their political objectives. Although it is not possible to attain formal statehood by a mere unilateral declaration of independence or pronouncement of the name of a prospective state, it has, nevertheless, been regarded as an important step in the process of creation of new states. For instance, the Jewish People's Council ${ }^{57}$ on 14 May 1948 proclaimed a new state named, the State of Israel in the territory called Eretz-Israel. ${ }^{58}$ In the Declaration, the term Eretz-Israel referred to the territory comprising the Mandate of Palestine. ${ }^{59}$ It is to be noted that, on 15 th November, 1988, the Palestine National Council (PNC) acknowledged establishment of the State of Palestine in the same territory with its capital at Jerusalem. ${ }^{60}$

The declaration of the name of a state pending formal attainment of statehood is a common practice especially in the cases of secession. A seceding unit's adoption of any name, designation or title in furtherance of attainment of statehood conveys the intention of establishing a new state. The secession of the 13 colonies from Great Britain under the name, the United States of America ${ }^{61}$ is an example of this kind of practice. ${ }^{62}$ On 4 July

Unification: The Yemen Arab Republic, 1962-1990' (1991) 23(4) International Journal of Middle Eastern Studies 483.

56 See generally Allen Buchanan, 'Theories of Secession' (1997) 26 Philosophy \& Public Affairs 31.

57 David Ben Gurion, the Chairman of the People's Council read out the Declaration of the Establishment of the State of Israel in the Hall of the Tel-Aviv Museum; See Samuel Sager, 'Israel's Provisional State Council and Government' (1978) 14 Middle Eastern Studies 91. See also Tuvia Friling and S Ilan Troen, 'Proclaiming Independence: Five Days in May from Ben-Gurion's Diary' (1998) 3 Israel Studies 170 .

58 See the Declaration of the Establishment of the State of Israel, available at <http://www.mfa.gov.il/MFA/Peace+Process/Guide+to+the+Peace+Process/Declaration+of+Esta blishment+of+State+of+Israel.htm> accessed 19 March 2013; The USA recognized the provisional Jewish government as de facto authority of the Jewish state immediately after the Declaration. De jure recognition was extended on 31 January 1949. The British Mandate over Palestine expired on 14 May 1948.

59 The word Palestine or Palaistinē (in Greek) was derived from Philistine - a term which denoted coastal region north and south of Gaza. The region was known as Purusati in Egyptian, as Palastu in Assyrian and as Pelëshet in Hebrew Bible. The Jews called the country Eretz Israel, the land of Israel. The first known occurrence of the Greek word Palaistine occurred in the Histories written by Herodotus near the mid-fifth century BC. See David M Jacobson, 'Palestine and Israel' (1999) 313 Bulletin of the American Schools of Oriental Research 65; Bernard Lewis, 'Palestine: On the History and Geography of a Name' (1980) 2 International Historical Review 1.

60 The Declaration of Independence was adopted by the Palestinian National Council, the legislative body of the Palestinian Liberation Organization (PLO), in Algiers on 15th November 1988. For the text of the Declaration see UNGA 'Declaration of Independence, in Letter dated November 18, 1988 from the Permanent Representative of Jordan to the United Nations addressed to the Secretary-General' (18 November 1988) UN Doc A/43/827-S20278 Annex III 13-16.

61 See Edmund C Burnett, 'The Name "United States of America"' (1925) 31 American Historical Review 79.The name, United States of America, appears to have been used for the first time in the Declaration of Independence. It should be mentioned that the while finalizing the Declaration of Independence, the 
1776, the 13 American colonies declared independence from Great Britain collectively coining themselves as the United States of America. ${ }^{63}$ Another example is the proclamation of independence by East Pakistan in 1971 assuming the title 'Bangladesh'. ${ }^{64}$ The disintegration of the Socialist Federal Republic of Yugoslavia (SFRY) and the consequent emergence of its constituent republics as sovereign states under different designations constitute a few more recent examples of practices concerning adoption of the official name by the seceding units. Of the constituent republics of SFRY, ${ }^{65}$ the Socialist Republic of Slovenia, the Socialist Republic of Croatia, the Socialist Republic of Macedonia and the Socialist Republic of Bosnia and Herzegovina between 1991 and 1992 all proclaimed independence between 1991 and 1992, adopting official designations namely, the Republic of Slovenia ${ }^{66}$, the Republic of Croatia, ${ }^{67}$ the Republic of Macedonia ${ }^{68}$ and the Republic of Bosnia and Herzegovina ${ }^{69}$ respectively - which better corresponded to their new identity as sovereign states. The remaining constituent republics of SFRY, namely, the Socialist Republic of Montenegro and the Socialist Republic of Serbia, on the other hand, claimed continuation of the international legal personality of SFRY under the designation of the Federal Republic of Yugoslavia (FRY) ${ }^{70}$ However, both the European Community ${ }^{71}$ and the United Nations ${ }^{72}$ were of

word 'States' was substituted for 'Colonies'. Later, the name, 'United States of America' was confirmed in Articles of Confederation as well as in the Constitution of the USA.

62 David Armitage, 'The Declaration of Independence and International Law' (2002) 59(1) The William and Mary Quarterly 39.

63 See Mark Tushnet, The Constitution of the United States of America. A Contextual Analysis (Hart Publishing 2009) 9-10.

64 Sheikh Mujibur Rahman declared Independence of Bangladesh on 26 March 1971. The Proclamation of Independence which was later adopted on 10 April 1971 reaffirmed Sheikh Mujibur Rahman's declaration of independence. See the Proclamation of Independence of Bangladesh (10 April 1971) reprinted in the Constitution of the People's Republic of Bangladesh (Government of the People's Republic of Bangladesh 2011) 79-80.

65 The constituent republics of the SFRY were the Socialist Republic of Bosnia and Herzegovina, the Socialist Republic of Croatia, the Socialist Republic of Macedonia, the Socialist Republic of Montenegro, the Socialist Republic of Serbia and the Socialist Republic of Slovenia. See the Constitution of Socialist Federal Republic of Yugoslavia (21 February1974) art 2 reprinted in Snežana Trifunovska (ed), Yugoslavia Through Documents: From Its Creation to Its Dissolution (Martinus Nijhoff Publishers 1994) 225.

66 UNSC 'Application of the Republic of Slovenia for Admission to Membership in the United Nations: note by the Secretary-General' (7 May 1992) UN Doc A/46/913-S/23885.

67 UNSC 'Application of the Republic of Croatia for Admission to Membership in the United Nations: note by the Secretary-General' (7 May 1992) UN Doc A/46/912-S/23884 Annex.

68 In view of differences between Greece and the Republic of Macedonia over the latter's name, the General Assembly decided that the latter would be referred to as 'the former Yugoslav Republic of Macedonia' for all purposes within the United Nations until resolution of the said differences. See UNGA Res 47/225 (8 April 1993) UN Doc A/RES/47/225.

69 UNSC 'Application of the Republic of Bosnia and Herzegovina for Admission to Membership in the United Nations: note by the Secretary-General' (19 May 1992) UN Doc A/46/921-S/23971.

70 Declaration of the Representatives of the people of the Republic of Serbia and the People of the Republic of Montenegro, in UNSC 'Letter dated 27 April 1992 from the Charge D'Affaires a.i. of the Permanent Mission of Yugoslavia to the United Nations addressed to the President of the Security Council' (5 May 1992) UN Doc S/23877 Annex.

71 The EC referred the matter to the Badinter Commission which came to the view that the process of dissolution of the SFRY had been completed and SFRY no longer existed; See Conference on Yugoslavia Arbitration Commission: Opinions on Questions Arising from the Dissolution of Yugoslavia, Opinion No.8 (4 July 1992) 31 ILM (1992) 1488, 1521-1523; See also Danilo Türk, 'Recognition of States: A Comment' (1993) 4 EJIL 87-88; Alain Pellet, 'The Opinions of the Badinter Arbitration: A Second Breath for the Self-Determination of Peoples' (1993) 3 EJIL 178.

72 See UNSC Res 777(1992) (19 September 1992) UN Doc S/RES/777 [1]; UNGA Res 47/1 (22 September 1992) UN Doc A/RES/47/1. 
the view that SFRY did no longer exist and its membership would be ipso facto rescinded as null and void. ${ }^{73}$

Adoption of a state name or analogous identity is commonplace when a constituent unit decides to break away from the parent state either in the exercise of constitutional right or through a mutually agreed political process. For instance, Montenegro declared independence on 3rd June, 2006, under the name of the Republic of Montenegro following the results of the referendum held on 21st May, 2006 in accordance with article 60 of the Constitutional Charter of the State Union of Serbia and Montenegro. ${ }^{74}$ The adoption of names such as Czech Republic and Slovak Republic following the break-up of Czechoslovakia constitutes another example of this kind of practice. ${ }^{75}$ The disbandment of the Union of Soviet Socialist Republics (USSR) deserves special mention in this regard. ${ }^{76}$ The USSR comprised fifteen federating units ${ }^{77}$ which were commonly known as the Republics of the Soviet Union or the Union Republics. ${ }^{78}$ In between 1990 and 1991, all the constituent republics of the USSR proclaimed independence, one after the other. ${ }^{79}$ The leaders of the present Russian Federation, Ukraine and the Republic of Belarus convened in a meeting at Minsk on 8th December, 1991 and made a joint declaration on establishing a Commonwealth of Independent States stating that the de facto process of withdrawal of republics from the Union of Soviet Socialist Republics and the formation of independent States had become a reality.$^{80}$ From the legal point of view, the USSR ceased to exist with the establishment of the Commonwealth of Independent States. ${ }^{81}$ From the Declaration by the Heads of the State on 8th December, 1991, it appears that the Ukrainian Soviet Socialist Republic and Byelorussian Soviet Socialist Republic respectively adopted new designations befitting their newly acquired status and identity, such as, Ukraine and the Republic of Belarus, and Russian Soviet Federative Socialist Republic was referred to by its abbreviated form of name, RSFSR. Moreover, on the very same day, the Russian Soviet Federative Socialist Republic changed its name to Russian Federation (RSFSR) in the Agreement Establishing the Commonwealth of

73 See Yehuda Z Blum, 'UN Membership of the "New” Yugoslavia: Continuity or Break?' (1992) 86 AJIL 830.

74 UNSC 'Letter dated 24 May 2006 from the Permanent Representative of Austria to the U.N. SecretaryGeneral' (26 May 2006) UN Doc S/2006/335 Annex; UNSC 'Letter dated 7 June 2006 from the Permanent Representative of Austria to the U.N. Secretary-General' (16 June 2006) UN Doc S/2006/412 Annex.

75 Czechoslovakia was an original Member of the United Nations from 24 October 1945. See UN, the Yearbook of the United Nations (1993) $1334<$ https://unyearbook.un.org/>.

76 The Treaty of Union was concluded between the Russian Socialist Federated Soviet Republic, the Socialist Soviet Republic of the Ukraine, the Socialist Soviet Republic of Belorussia, and the Socialist Soviet Republic of Transcaucasia (comprising the Socialist Soviet Republic of Azerbaijan, the Socialist Soviet Republic of Georgia, and the Socialist Soviet Republic of Armenia) for creating a single federal State. See Richard Sakwa, The Rise and Fall of the Soviet Union, 1917-1991 (Routledge 1999) 138.

77 See Yehuda Z Blum, 'Russia Takes over the Soviet Union's Seat at the United Nations' (1992) 3 EJIL 354.

78 Under the Treaty of Union, the constituent member republics were allowed to retain the right to withdraw freely from the USSR. The right to withdraw from the Union was further incorporated in the 1924 USSR Constitution. See Sakwa (n 76) 139.

79 Blum (n 77) 355. See also Rein Mullerson, 'The Continuity and Succession of States, by Reference to the Former USSR and Yugoslavia' (1993) 42 ICLQ 480-483.

80 See Declaration by the Heads of State of Belarus, Russia and Ukraine (8 December 1991) 31 ILM (1992) 142.

81 The Alma-Ata Declaration stated that with the establishment of the Commonwealth of Independent States, the Union of Soviet Socialist Republics ceased to exist. See Alma Ata Declaration (December $21,1991)$ reprinted in 31 ILM (1992) 148-149. 


\section{Independent States. ${ }^{82}$}

The following example shows how the possessors of the constituent capacity and the possessors of the sovereign capacity can mutually settle the issue of identity of a forthcoming state in the course of their negotiation over the terms of creation of a new state. The Sudan People's Liberation Movement (SPLM)/Sudan People's Liberation Army and the Government of the Republic of the Sudan signed the Comprehensive Peace Agreement on 9th January, 2005 with a view to bringing 21 years of conflict to a denouement. ${ }^{83}$ Although the term 'Southern Sudan' appeared in the Chapeau of the Comprehensive Peace Agreement so as to denote the then Sudanese regions meant to be represented by the Sudan People's Liberation Movement ${ }^{84}$, in the Machakos Protocol and other associated instruments appeared the term 'South Sudan' instead. Finally, the Comprehensive Peace Agreement notes that Southern Sudan should be changed to South Sudan in all the Protocols and Agreements. ${ }^{85}$ The ruling Sudan People's Liberation Movement officially adopted the name, the Republic of South Sudan for the newly established state which formally came into existence on 9th July, $2011{ }^{86}$

The foregoing discussion elucidates that the founders as well as states or sovereigns viewed the issue of name and naming of prospective states with paramount importance. In most of the cases, a prospective state's name continues as the official identity even after formal ordination into statehood. The fact that prospective states adopt names to manifest their identities well indicates that, alongside population, territory, government and capacity to enter into relations with other states, the nom de guerre deserves to be counted and equally ranked as a constituent element of statehood.

\section{Replacement and Extinction of State Name}

It has already been discussed that public manifestation of a prospective state's identity through a representative name has been regarded as a crucial desideratum in connection with the creation of new states. This part will provide an account of practices concerning the replacement of state name and other related issues. The discussion in this part underlines the fact that although a state may change its name whenever it may deem appropriate, it simply cannot do without a name until the extinction of its legal personality. Theoretically, after coming into formal existence, a state is formally vested with the sovereign right to determine its own name, just as it is to choose its national flag, and national anthem. ${ }^{87}$ Some scholars regard it as either a simple corollary of

82 See the Agreement Establishing the Commonwealth of Independent States (8 December 1991) reprinted in 31 ILM (1992) 143-146.

83 See UNSC 'Comprehensive Peace Agreement between the Government of the Republic of the Sudan and the Sudan People's Liberation Movement/ Sudan People's Liberation Army, in Letter dated 8 February 2005 from the Permanent Representative of the Sudan to the United Nations addressed to the President of the Security Council' (10 February 2005) UN Doc S/2005/78 iii.

84 ibid xi-xii.

85 ibid 233; The General Provisions in List of Corrections in the Protocols and Agreements (signed on 31 December 2004) clause 1.1.

86 See ST, 'SPLM adopts South Sudan name, untangles its northern sector' (Suan Tribune, 13 February 2011) <http://www.sudantribune.com/SPLM-adopts-South-Sudan-name,37985> accessed 01 December 2012. The President, Mr. Salva Kiir Mayardit, on the same date applied to the UN for admission to membership on behalf of the Republic of South Sudan. See UNGA 'Application of the Republic of South Sudan for Admission to Membership in the United Nations' (9 July 2011) UN Doc A/65/900-S/2011/418 Annex.

87 James Crawford as a Senior Counsel and Advocate of Greece put forward this argument in the case concerning Application of the Interim Accord of 13 September 1995 (the former Yugoslav Republic of Macedonia $v$ Greece). See Application of the Interim Accord of 13 September 1995 (the former Yugoslav Republic of 
sovereignty, or as part of basic self-preservation principles. ${ }^{88}$ In a similar vein, it can also be argued that it is the corollary of sovereignty that a state can dispose of its territory, change the form of government, determine the conditions of nationality and even compromise its sovereign power by treaty or otherwise. However, just as a state cannot strip itself of any or all of the traditionally recognised elements of statehood for good (if it wants to continue its statehood), it cannot dispense with its name altogether.

Additionally, the change of name is indubitably intertwined with change in identity of a state. A state's identity can never be static, as that would engender absolute thwarting of progress. It evolves, transforms and changes over time. Change in identity of a state may occur for a variety of reasons such as changes in social, religious or political system, territorial redistribution, disintegration of statehood, unification of states etc. For example, three regions under Austro-Hungarian rule, namely, Serbia, Croatia, and Slovenia, began to crave for independence and for a union of Slavic peoples particularly before and during World War I. The Kingdom of Serbs, Croats, and Slovenes was proclaimed on 1st December, 1918 following a series of initiatives including the 1917 Declaration of Corfu, ${ }^{89}$ the Geneva Declaration of 9th November, $1918,{ }^{90}$ and so on. ${ }^{91}$ The state was further renamed Kingdom of Yugoslavia in 1929.92 Since then the appellation Yugoslavia has been further qualified with the words, Democratic Federal, ${ }^{93}$ Federal Peoples Republic of ${ }^{94}$ and Socialist Federal Republic of ${ }^{95}$ from time to time. The case of Myanmar may be cited as one of the recent examples. By a treaty signed in London on 17th October, 1947, the United Kingdom recognised the Republic of the Union of Burma as a fully independent sovereign state. ${ }^{96}$ Shortly thereafter, the Ambassador of Burma on behalf of his government applied for membership of the UN intimating the Secretary-General of the UN that sovereignty over Burma had passed from the British Crown to the Burmese people on 4th January, 1948. The Ambassador, however, in his letter referred to the applicant state as Union of Burma and described his designation as the Ambassador of Burma. ${ }^{97}$ The UN approved the membership of the aforesaid applicant state by the name, the Union of Burma ${ }^{98}$ which later adopted the

Macedonia v Greece) (Verbatim Record of Oral Proceedings 30 March 2011) ICJ CR 2011/12 32 <http://www.icj-cij.org/docket/files/142/16390.pdf> accessed 17 August 2013.

88 See Francesco Messineo, 'Maps of Ephemeral Empires: The ICJ and the Macedonian Name Dispute' (2012) 1 Cambridge Journal of International \& Comparative Law 175.

89 Trifunovska (n 65) 141-142.

90 Geneva Declaration, 9 November 1918; Trifunovska (n 89) 149-150.

91 See Proclamation of the Kingdom of Serbs, Croats, and Slovenes (1 December 1918). Trifunovska (n 89) $157-158$.

92 King Alexander made announced the change of name on 3 October 1929; See Anonymous, 'Kingdom of Yugoslavia' (1929) 91(6) Advocate of Peace through Justice 355. See also Henry Baerlein, The Birth of Yugoslavia (London Parsons 1922) 271.

93 This particular style of name appeared in the 1943 Declaration of Anti-Fascist Council of the People's Republic of Yugoslavia and other related documents issued on 29 November 1943. See Trifunovska (n 65) 202-210.

94 The Constitution of the Federal People's Republic of Yugoslavia, 31 January 1946; Trifunovska (n 65) 212.

95 Trifunovska (n 65) 224.

96 See the Treaty between the Government of the United Kingdom of Great Britain and Northern Ireland and the Provisional Government of Burma Regarding the Recognition of Burmese Independence and Related Matters (1948) 2(3) CUP 183-184.

97 UNGA 'Letter from the Ambassador of Burma Addressed to the Secretary-General, dated February 27, 1948, Concerning the Application of Burma for Membership in the United Nations' (28 February 1947) UN Doc S/687.

98 UNSC Res 45(1948) (10 April 1948) UN Doc S/RES/45(1948); UNGA Res 188(S-2) (19 April 1948) UN Doc A/RES/188(S-2); UNSC 'Report to the Security Council by the Committee on the Admission 
following names such as, Socialist Republic of the Union of Burma on 4th January, 1974, before reverting to the Union of Burma again on 23rd September, 1988. On 18th June, 1989, the State Law and Order Restoration Council adopted the name Union of Myanmar. ${ }^{99}$ The official name of the said country since 30th March, 2011 is the Republic of the Union of Myanmar. ${ }^{100}$ Likewise, the Democratic Republic of the Congo at the time of gaining independence was known as the Republic of Congo. ${ }^{101}$ The Democratic Republic of the Congo changed its name to the Republic of Zaire on 27th October, 1971. ${ }^{102}$ Thereafter, the name, the Republic of Zaire was replaced with the Democratic Republic of the Congo in 1997. ${ }^{103}$ On the other hand, Congo-Brazzaville adopted the name the Republic of the Congo immediately upon gaining independence. ${ }^{104}$ Later, the Republic of the Congo changed its name to Congo (People's Republic of) in $1971 .^{105}$ Likewise, the Union of India adopted Bharat as an alternative name while adopting its Constitution. ${ }^{106}$ In 1949, Ireland was declared a republic with a new designation namely, Republic of Ireland. The United Republic of Tanganyika and Zanzibar adopted the name, United Republic of Tanzania. ${ }^{107}$ Ceylon changed its name to the Republic of Sri Lanka in 1972. ${ }^{108}$ The name United Arab Republic was changed to Arab Republic of Egypt in $1971 .^{109}$ The People's Democratic Republic of Yemen was successively listed as Southern Yemen, People's Republic of Southern Yemen, People's Democratic Republic of Yemen and Democratic Republic of Yemen before merging with Yemen Arab Republic to form the Republic of Yemen. ${ }^{110}$

of New Members Concerning the Application of the Union of Burma for Membership in the United Nations' (30 March 1948) UN Doc S/706.

99 See the Yearbook of the United Nations (1989) 972.

${ }_{100}$ Article 2 of the Myanmar Constitution provides that the State is officially known as the Republic of the Union of Myanmar. See The Constitution of the Republic of the Union of Myanmar, art 2 $<$ https://treaties.un.org/Pages/HistoricalInfo.aspx\#Myanmar> accessed 31 August 2021.

101 The application of the Republic of Congo's for admission to the UN was submitted under the signature of Patrice Lumumba who described himself as Prime Minister of the Government of the Republic of Congo. See UNSC 'Cable dated 1 July 1960 from the Prime Minister of the Government of the Republic of Congo Addressed to the U.N. Secretary-General' (1 July 1960) UN Doc S/4361. The Republic of Congo was nonetheless referred to as 'the Republic of the Congo' and 'the Republic of Congo (Leopoldville)' respectively in the Security Council and the General Assembly resolutions concerning its admission to the UN. See UNGA Res 1480 (XV) (20 September 1960) UN Doc A/RES/1480(XV); UNSC Res 142 (7 July 1960) UN Doc S/RES/142.

102 See the Yearbook of the United Nations (1971) 766; In the 1964 Yearbook of the United Nations, the Republic of Congo was referred to as Democratic Republic of Congo. In the 1965 Yearbook of the United Nations, the Republic of Congo was referred to as Democratic Republic of the Congo. In the earlier UN Yearbooks from 1961-1963, the Republic of Congo was referred to as Congo (Leopoldville).

103 The change was made on 17 May 1997. See the Yearbook of the United Nations (1997) 1574.

${ }^{104}$ The only difference between names of the two states once appeared to be an extra 'the' before 'Congo'. cf UNSC 'Cable dated 15 August 1960 from the Head of State of the Republic of the Congo Addressed to the U.N. Secretary-General' (15 August 1960) UN Doc S/4433 and UNSC 'Cable dated 1 July 1960 from the Prime Minister of the Government of the Republic of Congo Addressed to the U.N. SecretaryGeneral' (1 July 1960) UN Doc S/4361.

${ }_{105}$ The Yearbook of the United Nations 1971 (n 102) 766.

106 Constitution of India (1949) art 1.

${ }^{107}$ In a communication addressed to the UN Secretary-General on 2 November 1964, the Permanent Mission of the United Republic of Tanganyika and Zanzibar informed that the country would be known as the United Republic of Tanzania with immediate effect. See the Yearbook of the United Nations (1964) 580.

${ }^{108}$ See the Yearbook of the United Nations (1972) 824, Sri Lanka was admitted to the UN under the name, Ceylon. See also UNGA Res 995(X) (14 December 1955) UN Doc A/RES/995(X).

109 The Yearbook of the United Nations 1971, (n 102) 766.

110 United Nations Treaty Collection <http://treaties.un.org/Pages/HistoricalInfo.aspx?\#"Yemen"> accessed 16 August 2021. 
Needless to say, the corollary of adoption of a new name by a state is that the new name will supersede the earlier one. The previous name may either fall into disuse or continue as the municipal name, as the case may be. For example, when two or more states unify themselves into a new state, adoption of a new designation for the new state may have the effect that the names of the conjoining states will lose their status as state names and relegate to municipal names (the reason being that the conjoining states in such cases will become the municipal units of the new state). As discussed earlier, the denominations such as, Egypt and Syria had had similar consequence while forming the United Arab Republic. The provisional Constitution of the United Arab Republic (U.A.R.) provided that the new state would consist of two regions namely, Egypt and Syria. ${ }^{111}$ In comparison to the above examples, the withdrawal of the then Syrian region from the United Arab Republic (U.A.R.) and the subsequent use of the name, Syrian Arab Republic show that a federating unit may adopt its former designation after reverting to its previous identity as a sovereign state. ${ }^{112}$ Similarly, in the case of annexation, the name of the annexed state may become a municipal name or be faced with extinction depending on the circumstances since the annexed state may continue as a municipal unit or lose its political or administrative existence altogether. A notable example is the annexation of Korea by Japan. ${ }^{113}$ Evidently, in any of the aforesaid situations, the current or previous name of a former state may not be altogether bereft of historical or referential value.

The name of a state may fall into disuse in consequence of the cessation of the legal personality of the state concerned. Generally, the legal personality of a state ceases to exist as an ipso facto corollary of either disintegration of a state or unification or merging of several states. In this article, the disuse of the name of a state in consequence of cessation of statehood is termed the extinction of a state name. The dismemberment of Czechoslovakia and the Union of Soviet Socialist Republics (USSR), along with the consequent abandonment of these designations, are the examples of disintegration paradigm. In contrast, the absorption of German Democratic Republic into Federal Republic of Germany with the resultant effect of the dissolution of the former's statehood and abolition of its name may serve as an example of the latter. ${ }^{114}$ The German Democratic Republic acceded to Federal Republic of Germany on 3rd October, $1990^{115}$ in furtherance of the Unification Treaty of 31st August, 1990. ${ }^{116}$ With the accession of the

111 The Provisional Constitution of the United Arab Republic (5 March 1958) art 58. It may be noted that the way Egypt and Syria were mentioned in Article 58 of the aforesaid Provisional Constitution sufficiently indicates that their status as sovereign states had changed to municipal unit.

${ }^{112}$ See UNSC 'Cable dated 8 October 1961 from the Prime Minister and Minister for Foreign Affairs of the Syrian Arab Republic addressed to the President of the General Assembly' (9 October 1961) UN Doc A/4914-S/4958. See also UNSC 'Cable dated 30 September 1961 from the Prime Minister and Minister for Foreign Affairs of the Syrian Arab Republic addressed to the President of the General Assembly' 9 October 1961) UN Doc A/4913-S/4957.

113 See Treaty Annexing Korea to Japan (29 August 1910) 282-283. See also Editorial Comment, 'The Annexation of Korea to Japan' (1910) 4 AJIL 923-925.

114 About the admission of the German Democratic Republic and Federal Republic of Germany to the UN, see UNSC Res 335 (22 June 1973) UN Doc S/RES/335. See also UNGA Res 3050(XXVIII) (18 September 1973) UN Doc A/RES/3050(XXVIII).

115 The then Prime Minister of German Democratic Republic by a letter to the UN Secretary-General informed that with this accession, the membership of German Democratic Republic in the UN and other intergovernmental organizations would cease forthwith. See UNGA 'Letter dated 27 September 1990 from the Prime Minister of the German Democratic Republic to the U.N. Secretary-General' (28 September 1990) UN Doc A/45/557 Annex.

116 The Treaty between the Federal Republic of Germany and the German Democratic Republic on the Establishment of German Unity (Unification Treaty) (31 August 1990) art 1. 
German Democratic Republic to Federal Republic of Germany, the two German States had merged to form one state as a single member of the United Nations. It was also decided that from the date of unification, the Federal Republic of Germany would function in the United Nations under the title of Germany. ${ }^{117}$

In international law, there appears to be no prohibition against the use of an extinct state's name by another state. However, that does not mean that an adopting state can overlook the nexus between its identity and the official denomination while using an extinct state's name. The case of the Federal Republic of Yugoslavia presents an interesting case in point in this regard. In the course of dissolution of the Socialist Federal Republic of Yugoslavia (SFRY), Montenegro and Serbia claimed continuation of the international legal personality of SFRY under the name of the Federal Republic of Yugoslavia (FRY). However, the European Community ${ }^{118}$ as well as the United Nations ${ }^{119}$ was of the view that SFRY had ceased to exist and therefore, FRY would not automatically continue the membership of SFRY. Under the circumstances, FRY applied afresh in 2000 for admission to membership of the UN in compliance with the Security Council Resolution 777 (1992). ${ }^{120}$ In 2003, the name, FRY was further changed to Serbia and Montenegro. ${ }^{121}$ It may be noticed that the name, FRY was adopted when the state concerned claimed succession to SFRY. Later, the name, Serbia and Montenegro was adopted, perhaps because FRY could no longer serve as the appropriate denomination of the said state's identity. ${ }^{122}$

The fact that a state cannot afford to dispense with its name does not mean that it must adopt a unique designation. Hence, commonality of name among two or more states is not quite uncommon, although, ironically, in most of such cases, states sharing the commonality of name have strained relationships. It is generally accepted as sufficient, if any prefix or suffix which complements such common denomination makes their respective names as a whole identifiably different. The bottom line is that unique or not, a state must have a name.

\section{Dispute over State Name: A Case Study}

By now it is evidently clear that the identity or name of any state or prospective state can be the subject matter of intriguing issues. For example, if a state has absolute autonomy

117 UNGA 'Note Verbale dated 3 October 1990 from the Secretary General to the Permanent Representative of Member States' (3 October 1990) UN Doc A/45/567; According to Professor James Crawford, the identity and legal personality of German Democratic Republic as a separate state had been dissolved into the identity and legal personality of Federal Republic of Germany as a result of the unity; Crawford (n 42) 705.

118 Conference on Yugoslavia Arbitration Commission (n 71).

119 UNSC Res 777(1992) (19 September 1992) UN Doc S/RES/777.

120 UNGA 'Application of the Federal Republic of Yugoslavia for Admission to Membership in the United Nations: note by the Secretary-General' (30 October 2000) UN Doc A/55/528-S/2000/1043. See also UNGA Red 55/12 (10 November 2000) UN Doc A/RES/55/12; UNSC Res 1326 (31 October 2000) UN Doc S/RES/1326(2000).

121 The change of name became effective following adoption of the Constitutional Charter of Serbia and Montenegro on 4 February 2003. See UNGA 'Letter dated 4 February 2003 from the Permanent Representative of Serbia and Montenegro to the U.N. Secretary-General' (10 February 2003) UN Doc A/57/728-S/2003/170; Serbia and Montenegro again broke up in 2006 as Montenegro declared itself an independent state under the name of the Republic of Montenegro; UNSC 'Letter dated 7 June 2006 from the Permanent Representative of Austria to the U.N. Secretary-General' (n 74).

${ }^{122}$ In the author's opinion, the appellation, Yugoslavia thus got altogether removed from the official titles of the former constituent republics of SFRY. Nevertheless, the Former Yugoslav Republic of Macedonia continued to be used within the UN-which, however, was not the official name of the then Republic of Macedonia. 
to adopt any name whatsoever, or conversely; if a state's name should reflect its purported identity; if a state has the right to be addressed by other states by the name it has chosen for itself, or, putting it differently, if a state, by adopting a name, creates an obligation on other states to call it by the name it has chosen for itself; if an international organisation has the authority to apply such denomination to any of its member states, which is different from the official title of the state concerned etc.

The dispute over name between Greece and the then Republic of Macedonia illustrates all of the above-mentioned issues. In the aftermath of the break-up of Yugoslavia, the Assembly of the Socialist Republic of Macedonia adopted the Declaration on the Sovereignty of the Socialist Republic of Macedonia on 25 January 1991. On 7 June 1991, the said Assembly enacted a constitutional amendment, changing the name from Socialist Republic of Macedonia to the Republic of Macedonia. The Assembly then adopted a declaration asserting the sovereignty and independence of the new state and sought international recognition. ${ }^{123}$ The then Republic of Macedonia's request for $\mathrm{EC}$ recognition was considered by the Badinter Commission in the light of the EC's 16 December Guidelines and its Declaration on Yugoslavia which included among others the condition that a Yugoslav Republic would refrain from using such denomination as this would imply territorial claims towards a neighbouring state. ${ }^{124}$ The Badinter Commission finally decided that Macedonia satisfied all the tests for recognition and that the use of the name 'Macedonia' did not imply any territorial claim against another state. ${ }^{125}$ However, the EC eventually declined to accord recognition to the Republic of Macedonia. The EC expressed that they were willing to recognize Macedonia as a sovereign and independent state within its existing borders but under a name that would be accepted by all the parties concerned. In its statement, the EC addressed the Republic of Macedonia as the Former Yugoslav Republic of Macedonia. ${ }^{126}$ At the EC Lisbon Summit of 26-27 June of 1992, the EC again expressed its willingness to extend recognition to Macedonia if under a name that would not include the term Macedonia. ${ }^{127}$

In January of 1993, the then Republic of Macedonia applied for membership in the UN. ${ }^{128}$ Addressing the applicant state as the Former Yugoslav Republic of Macedonia, Greece registered a prompt reaction. ${ }^{129}$ Greece contended that admission of the applicant state to UN membership prior to meeting the necessary prerequisites- in particular abandoning the use of the denomination Republic of Macedonia- would not be conducive to peace and stability in that region. ${ }^{130}$ Greece argued that the adoption of the

123 See Application of the Interim Accord of 13 September 1995 (the former Yugoslav Republic of Macedonia $v$ Greece) (Judgment) [2011] ICJ Rep 1026 [15] <http://www.icj-cij.org/docket/files/142/16827.pdf> accessed 14 August 2013.

124 Declaration on Yugoslavia and on the Guidelines on the Recognition of New States, reprinted in 31 ILM (1992) 1485-1487. See also Roland Rich, 'Recognition of States: The collapse of Yugoslavia and the Soviet Union' (1993) 4 EJIL 51-53.

125 Rich (n 124) 52.

126 ibid.

127 Presidency Conclusions, at 42, Lisbon European Council (26-27 June 1992), available at <http://www.europarl.europa.eu/summits/lisbon/li2_en.pdf> accessed 15 August 2013.

128 UNGA 'President of the Republic of Macedonia to the U.N. Secretary-General, Letter dated 30 July 1992 from the President of the Republic of Macedonia addressed to the U.N. Secretary-General: note by Secretary General' (22 January 1993) UN Doc A/47/876-S/25147 Annex.

129 UNGA 'Memorandum from the Minister for Foreign Affairs of Greece, Concerning the Application of the former Yugoslav Republic of Macedonia for admission to the United Nations, in Letter dated 25 January 1993 from the Permanent Representative of Greece to the United Nations addressed to the Secretary-General' (25 January 1993) UN Doc A/47/877-S/25158 Appendix [1].

130 ibid [5-8]. 
name Republic of Macedonia in a way represented the differences between two states. ${ }^{131}$ The Committee on the Admission of the New Members in its proposed draft resolution omitted to refer the applicant state by name. Rather the draft resolution addressed the Republic of Macedonia as the State whose application is contained in document S/25147 and also recommended that it should be referred to as the Former Yugoslav Republic of Macedonia for all purposes within the United Nations pending settlement of differences over name. ${ }^{132}$ Greece noted with satisfaction that admission of the applicant state under such a provisional name would be an acceptable measure that could help resolve the differences between two states. ${ }^{133}$ Accordingly, the Security Council passed a resolution recommending for admission of the applicant state. ${ }^{134}$ The President of the Security Council clarified that the term, the Former Yugoslav Republic would carry no implication that the state concerned had had any connection with the Federal Republic of Yugoslavia (Serbia and Montenegro). ${ }^{135}$ The General Assembly passed its respective resolution in line with the Security Council resolution. ${ }^{136} \mathrm{Mr}$. Kiro Gligorov, the then President of Macedonia, in his address to the General Assembly, referred to his country by its constitutional name, the Republic of Macedonia, while all other states, including Greece, referred to the new member state as the Former Yugoslav Republic of Macedonia. ${ }^{137}$ On 18th June 1993, the Security Council passed Resolution 845 (1993) urging the two states to continue their efforts under the auspices of the Secretary-General to arrive at a speedy settlement of the remaining issues between them. ${ }^{138}$ Against this backdrop, Greece and Macedonia signed an Interim Accord on 13th September 1995 providing for the establishment of diplomatic relations between them and addressing other related issues. ${ }^{139}$ The Interim Accord referred to Greece as 'Party of the First Part' and Macedonia as 'Party of the Second Part' so as to avoid using the respective names of the state parties. In April 2008, Macedonia's candidacy for NATO was considered in a meeting of NATO member states in Bucharest. The communiqué issued at the end of the Summit stated that an invitation would be extended to the applicant state as soon as a mutually acceptable solution to the name issue would have been reached. ${ }^{140}$ This led Macedonia to bring a case to the International Court of Justice against Greece for breach of the Interim Accord. ${ }^{141}$ Eventually, in 2019, the two countries resolved their dispute over the name, after almost three decades, by concluding an agreement to the effect that

131 Greece threatened that it would not recognize Macedonia if its contentions were not addressed; ibid [15]; In the meantime, Macedonia objected to the designation the former Yugoslav Republic of Macedonia. See UNSC 'Letter dated March 24, 1993 from the Republic of Macedonia Government: note by UN President of the Security Council' (6 April 1993) UN Doc S/25541 Annex.

132 UNSC 'Report of the Committee on the Admission of New Members Concerning the Application for Admission to Membership in the United Nations Contained in Document S/25147' (7 April 1993) UN Doc S/25544.

133 UNSC 'Letter dated April 6, 1993 from the Permanent Representative of Greece to the United Nations addressed to the President of the Security Council' (6 April 1993) S/25543 Annex.

134 UNSC Res 817(1993) (7 April 1993) UN Doc S/RES/817(1993).

135 UNSC 'Note by the President of the Security Council' (7 April 1993) UN Doc S/25545.

136 UNGA Res 47/225 (8 April 1993) UN Doc A/RES/47/225. Greece was among the states that sponsored the draft General Assembly resolution on admission of Macedonia to UN membership. See Draft UN Doc A/47/L.54 (7 April 1993).

137 UNGA Res 47/225 GAOR 98 ${ }^{\text {th }}$ Plenary Session (13 April 1993) UN Doc A/47/PV.98.

138 UNSC Res 845(1993) (18 June 1993) UN Doc S/RES/845.

139 UNSC 'Interim Accord, in Letter dated 13 September 1995 from the Secretary-General Addressed to the President of the Security Council' (14 September 1995) UN Doc S/1995/794 Annex-I.

140 The former Yugoslavia Republic of Macedonia v Greece (n 123) [22].

141 The Court found that Greece by objecting to admission of the Former Yugoslav Republic of Macedonia to NATO breached its obligation under article 11 of the Interim Accord of 13 September 1995; ibid [169-170]. 
the Republic of Macedonia would change its name to the Republic of North Macedonia. ${ }^{142}$ As a result, North Macedonia was able to join NATO. ${ }^{143}$

In this dispute, the main concern of Greece was that the name, Macedonia, referred to a wider geographical region, extending over four neighboring countries, with only $38.5 \%$ within its existing borders. The exclusive use of Macedonia as the state's official name, in the opinion of Greece, could become a reason for its expansionist claims in the future. ${ }^{144}$ Basically, Greece's concern was that the name, Macedonia, did not reflect the actual identity of the state which adopted it. Consequently, Greece demanded that the name Republic of Macedonia should be abandoned to mitigate tension in that region. ${ }^{145}$ What actually transpired from Greece's position was that Greece had identified its concern over the supposed expansionist ambition of Macedonia with the latter's official name. Arguably, if Macedonia really wanted to pursue its territorial claim against Greece, the change of Macedonia's official name at the behest of Greece would not be enough to deter it from doing so, nor would it signify relinquishment of the country's supposed territorial claim against Greece. ${ }^{146}$ The Greco-Macedonian name dispute has shown that a state's name needs to be appropriately aligned with its identity, failing which difference can arise and develop into full-scale international disputes. ${ }^{147}$ What it further elucidates is that, although it is the general practice that states address each other by the names they have respectively chosen for themselves, a state may object to the adoption of a certain name by another state and refrain from using the same if and when the circumstances warrant.

The extent of authority of an international organization to deal with situations concerning differences between member states over their names, as may be argued, should be determined in accordance with the instrument by which the international organisation has come into being. Such authority, if there exists any, should be applicable only to the member states of the concerned international organisation. It may be noted that although the Security Council omitted to address Macedonia by name, it recommended to the General Assembly to refer the applicant state as 'The Former Yugoslav Republic of Macedonia' for all purposes within the United Nations till settlement of difference over its name. ${ }^{148}$ The General Assembly admitted Macedonia to membership first and then determined to address it as the Former Yugoslav Republic of Macedonia following orders from the Security Council. ${ }^{149}$ From the legal point of view, one may legitimately question whether the General Assembly and the Security Council

${ }^{142}$ See Article 1 of the Final Agreement for the Settlement of the Differences as Described in the United Nations Security Council resolutions 817 (1993) and 845 (1993), the Termination of the Interim Accord of 1995, and the Establishment of a Strategic Partnership between the Parties, in Identical letters dated 13 February 2019 from the Secretary-General addressed to the President of the General Assembly and the President of the Security Council (14 February 2019) UN Doc A/73/745-S/2019/139 Annex-I. With the Final Agreement's entry into force, the Interim Accord of 1995 terminated.

143 Helena Smith, 'Macedonia Officially Changes its Name to North Macedonia' (The Guardian, 2019) <https://www.theguardian.com/world/2019/feb/12/nato-flag-raised-ahead-of-north-macedoniasprospective-accession> accessed 30 July 2020.

144 UN Doc A/47/877-S/25158 Appendix (n 129) [10].

145 ibid [15].

146 For an opposite view, see Dean M Poulakidas, 'Macedonia: Far More Than a Name to Greece' (1995) 18(2) HastingsIntl\&CompLRev 397.

147 In the author's view, the difference over name between Greece and Macedonia, having regard to the fact that only Greece raised objection in this regard, is a bilateral one-which Greece could have given a multilateral diffusion. See also Matthew CR Craven, 'What's in a Name? The Former Yugoslav Republic of Macedonia and Issues of Statehood' (1995) 16 AustYBIL 199.

${ }^{148}$ UN Doc S/RES/817(1993) (n 134) para 2.

${ }^{149}$ UN Doc A/RES/47/225 (n 136). 
acted within their respective boundaries of jurisdiction by deciding that a member state would be referred to by a designation which is different from the officially accepted one.

The Greco-Macedonian name dispute clearly delineates why it makes sense for a state to denominate its identity appropriately. It also epitomises the importance of name as the most suitable conveyor of a state's identity as a member of international community. The importance of a state's name is so fundamental that if an entity or a state does not want to address another state by the name the latter has chosen for itself, it will have to invent a name or designation to address such state whose name is being so disputed. Presumably, the Security Council understood the problem of not referring a state by any name at all and, therefore, took the practical decision to call the applicant state by a provisional name such as, 'The Former Yugoslav Republic of Macedonia'. ${ }^{150}$ Additionally, the EC's response to Macedonia's request for recognition shows that the whole idea and purpose of recognition will be rendered futile if states do not have distinguishable identities, for the recognition of one state by another is essentially premised on the concept of separate identity of states. In fine, the Greco-Macedonian name dispute perfectly portrays the importance of name as an attribute of statehood.

\section{Conclusion}

It could be gleaned from the previous discussion that a state's name is the most crucial instrument for manifesting its identity. Metaphorically speaking, the name of a state is the genetic code in which is encrypted the genesis of a people and their evolution into a state. Therefore, choosing a state's name has never been considered a free ride, nor does a state change its name randomly at will. This also explains why a state's name is chosen before formal attainment of statehood and it continues as the official designation afterwards. The claim that the name of a state can be regarded as an element of statehood becomes clear if considered from this point of view.

We now live in a world where states are increasingly engaging in more diverse international activities than ever before. Since states are identifying more and more common areas of interests and cooperation, multilateralism and collective cooperation in international relations have become the reality of today's international community life. Collective recognition of states, membership in international organizations, multilateral treaties, multilateral trade and resolution of disputes by judicial means, permanent diplomatic missions abroad, etc. have become the be-all and end-all of international community life, and it requires representation of the legal personalities of states more frequently than ever. How can it be possible for states to engage in these activities without manifesting their representative identities? This shows that the importance of a state's name, in the contemporary world of ubiquitous multilateral legal relationships, cannot be overemphasised. Hence, although no international custom or treaty has yet recognised a state's name as an element of statehood, the fact remains that a state, from its emergence to extinction, must have a name. 